\title{
Entrepreneurial Intentions and Its Influencing Factors: A Survey of the University Students in Xi'an China
}

\author{
Zhengxia Peng, Genshu Lu, Hui Kang \\ Institute of Higher Education, Xi'an Jiaotong University, Xi'an, China \\ Email: zxpeng@mail.xjtu.edu.cn
}

Received 2012

\begin{abstract}
Based on a survey of 2,010 senior university students from nine universities in Xi'an, China, this paper analyzes the student's entrepreneurial intention level and its influencing factors. The results show that the perceived subjective norm of university students has significantly positive influence on their entrepreneurial attitude and the entrepreneurial self-efficacy while all these factors influence their entrepreneurial intentions significantly. This paper also examines the influence of other factors such as individual/psychological factors, family background factors and social environment factors, and further discusses its policy implications.
\end{abstract}

Keywords: Entrepreneurship; Entrepreneurial Intention; University Students

\section{Introduction}

Entrepreneurship is a process of creation and of realizing values for entrepreneurs (Morris \& Jones, 1999). The entrepreneurial activities play quite important roles in promoting economic and social development. For these reasons, in recent decades, the problems of entrepreneurship are focused by lots of scholars and policy makers. Because of the development of mass higher education in China, the employment problem of university graduates is more and more serious. To solve this problem, Chinese government emphasizes promoting the employment by entrepreneurship and starts to encourage and support university graduates to create their own business. University graduates' employment by starting their own business is not only encouraged and advocated by government, but it is also the actual choice of graduates. However, at present there is a low proportion of entrepreneurship in Chinese graduates. To promote the entrepreneurship of graduates and drive the employment by entrepreneurship, it is necessary to explore the entrepreneurial intentions of university students and their influencing factors.

For more than fifty years, researches about entrepreneurship can be divided into the following stages: in 1960s, after the publication of The Achieving Society by McClelland(1961), researchers mainly focused on the effect of personality traits of entrepreneurs on their entrepreneurial behaviors. In 1980s and 1990s, researchers turned their attentions to the impact of individual intentions of entrepreneurship on their entrepreneurial behaviors. Meantime, the empirical study about entrepreneurial intentions and their influencing factors emerged in large numbers. Some researchers argued that compared with individual personality variable; individual intentions of entrepreneurship were more effective and had stronger explanatory ability in prediction of their entrepreneurial behaviors (Ajzen, 1987). During this period, six major entrepreneurial intention models were proposed, including the Entrepreneurial Event Model by Shapro (1982), the Theory of Planned Behavior by Ajzen (1991) and so on. Since the 21st century, some researchers put forth some new models on the basis of modifying and criticizing these models. For example, Elfving, Brännback, \& Carsrud (2009) pointed out those current entrepreneurial intentions models were often linear and static and put forth a Contextual Model of Entrepreneurial Intentions to avoid these limitations.

By analyzing current researches about individual's entrepreneurial intentions and their influencing factors, some problems can be found. One is that the influencing factors involved in current researches are often a partial rather than a comprehensive and systematic analysis. The other is that current researches mainly uses statistical methods like descriptive statistics, variance analysis, regression analysis, cluster analysis and path analysis, which are used to discuss the linear relation between the independent variables and dependent variables and are hard to present the relations between variables as a whole (Tabachnick \& Fidell, 2001). This inevitably leads to biased results.

To overcome these limitations in current researches, based on a sample survey conducted on 2,010 senior university students in nine different types of universities in Xi'an, China in 2009, this paper gives a more systematical and overall discussion about the influence of individual, family and social environment factors on the entrepreneurial intentions of university students. Furthermore, in order to discuss relations between variables as a whole, this paper applies structural equation modeling to verify the relation between the entrepreneurial intentions of university students and their influencing factors.

\section{Literature Review}

\section{Definition of Entrepreneurial Intentions and Their Measurements}

Individual's entrepreneurial intentions are the important variables to predict their entrepreneurial behaviors. But researchers have no an identical definition about individual's entrepreneurial intentions. On one hand, referring to individual's entrepreneurial intentions, the current literatures adopt some similar 
conceptions, like career orientation (Francis \& Banning, 2001), nascent entrepreneurs (Korunka,et al, 2003) and so forth. On the other hand, researchers often give operational definitions when they define individual's entrepreneurial intentions, resulting in discrepancy. This paper takes the senior university students who rarely engage in entrepreneurial activity as research objects. We define the entrepreneurial intention in this paper as a mental orientation such as desire, wish and hope influencing their choice of entrepreneurship.

Currently the measurement to individual's entrepreneurial intentions includes single variable method and multivariable method. Single variable method is to measure individual's entrepreneurial intentions by single variables such as individual's expectation, preference, plan, behavioral anticipation. It can also be divided into researcher judgment method and individual self-report method. Even though the single variable method is simple and clear, its validity and reliability are not so ideal because of over simplicity. Multivariable method is a method used by researchers to improve the validity and reliability of measurement. They judge individual's entrepreneurial intentions by multivariable or from various dimensions to reduce errors (Chen, Greene, \& Crick, 1998; Van Gelderen, et al, 2008).

\section{The Influencing Factors of Individual'S Entrepreneurial Intentions}

Researchers also have a deep and wide discussion on the influencing factors of individual's entrepreneurial intentions while measuring their entrepreneurial intentions. They propose many analyzing models, among which The Entrepreneurial Event Model by Shapero \& Sokol (1982) and The Theory of Planned Behavior by Ajzen(1991) are the representative ones. Some researchers have proposed new models about entrepreneurial intentions (Davidsson, 1995; Elfving, Brännback, \& Carsrud, 2009; Krueger \& Brazeal,1994). These models analyze many different factors affecting individual's entrepreneurial intentions. They can be divided into three categories: individual or psychological factors, family background factors and social and environmental factors.

\section{Individual/psychological factors}

Many researchers have explored the impact of individual's gender on their entrepreneurial intentions. Some researchers find that males have stronger intentions than females (Matthews \& Moser, 1995). Some argue that the low entrepreneurial intentions for females because of their low self-efficacy. They may avoid starting their own business for the lack of necessary capability (Fielden, et al, 2003). Some stereotyped images caused by their responsibilities of supporting the family, raising the children may have negative influence on females' entrepreneurial intentions (Lee, et al, 2011).

Researchers also focus on the personality traits' effect on individual's entrepreneurial intentions. Some researchers considered personality traits as an important factor. Compared with other people, entrepreneurs show some personality traits such as strong achivement orientation, strong individual control , willingness to take risks, endurance, and intelligence (Shaver, 1995), but other researchers hold that those personality traits cannot be taken as an effective explanation of their choice of starting business (Gartner,1985).

Some researches present that individual's attitudes to entrepreneurship are apparently related to their entrepreneurial behavior, which is mediated by intentions (Ajzen \& Fishbein,
1977). Ajzen(1991) points out individual's attitudes constitute the important influencing factors of their entrepreneurial intentions.

Krueger argue that individual's entrepreneurial intentions are also impacted by their subjective norm which is influenced by perceived expectation level from those who are important to him or her like relatives, parents, friends, colleagues and so forth to their certain behaviors and individual's obedience to these expectations (Krueger, 1993) .

The relation between the self-efficacy of individual's entrepreneurship and their entrepreneurial intentions has been verified by many researches (Chen, Greene \& Crick, 1998). Krueger \& Brazeal (1994) argue that individual's judgment on the feasibility of starting a business comes from the judgment on their self-efficacy of implementing and planning their entrepreneurial behavior. Boyd \& Vozikis (1994) state that self- efficacy influences not only the formation of individual's entrepreneurial intentions, but also the possibility of creating a firm in the future.

According to Garzón (2010), individual’s entrepreneurial competence plays a determinant role in the early stage of starting a business. McClelland (1961) indicates that adults' entrepreneurial intentions can be predicted by the entrepreneurial competence in their childhood. Thereafter, some scholars study on individual's entrepreneurial competences and their impact on entrepreneurial intentions from different perspectives (Bird, 1995; Chandler \& Jansen, 1992; Chen, Greene \& Crick, 1998). Man(2000) concludes that entrepreneurial competences are the integrated abilities by which entrepreneurs succeed in implementing entrepreneurial activities, including opportunity competencies, relationship competencies, conceptual competencies, organizing competencies, strategic competencies and commitment competencies. Even though at present a large number of researches about entrepreneurial competences exist, they seldom discuss the relationship between entrepreneurial competences and entrepreneurial intentions. Schmitt-Rodermund (2004) concludes that student's entrepreneurial competences refer to their leadership, curiosity and entrepreneurial skills which are influenced by personality traits and family's education.

Some researchers find that the prior entrepreneurial experiences may have impact on individual's entrepreneurial intentions (Krueger, 1993). Their prior entrepreneurial experiences can not only develop individual's entrepreneurial intentions, but can also accumulate experiences and skills for future entrepreneurial activities. Some researches, however, indicate that the prior entrepreneurial experiences just have slight influences on individual's knowledge of entrepreneurship and have no significant impact on their entrepreneurial attitudes (Davidsson, 1995).

\section{Family background factors}

Some researches discuss the impact of family background factors on individual's entrepreneurial intentions. Current researches explain families' impact on individual's entrepreneurial intentions mainly from role molding perspective and believe parents play an important role in children's entrepreneurial career. Nevertheless, some researches do not think parents' behaviors would set examples to influence children's entrepreneurial intentions (Churchill,et al,1987). Entrepreneurs' children do not proportionally become Entrepreneurs (Krueger \& Dickson, 1993).

Social environment factors

Stephen, Urbano, \& Hemmen (2005) state that social envi- 
ronment factors like legal rules, government support is an important factor influencing individual's entrepreneurship. Scholars indicate that social environment factor is an adjusting variable which impacts individual's entrepreneurial intentions by the interaction with individual's attitudes (Shapero \& Sokol, 1982). It is noteworthy that as Lüthje \& Frank (2003) mentioned there are both supporting and hindering factors among social environment factors.

Based on literature review above, this paper will provide a comprehensive analysis on the impact of individual/psychological factors, family background factors and social environment factors on individual's entrepreneurial intentions.

\section{Research Design}

\section{Research Sample}

We take senior university students from nine different types of universities in Xi'an, China in 2009 as subjects of our research. We take class as unit to investigate students from eleven majors in nine different universities which include national key universities, regular universities and independent colleges. Approximately 2,450 questionnaires were distributed and 2,165 were returned. There are 2,010 valid questionnaires including 1241 males and 769 females with a valid rate of 92.84 percent.

\section{Instruments}

Every student was required to finish a questionnaire which includes individuals' characteristics, families' social and economic status, individual's entrepreneurial intentions and their influencing factors.

The measuring instrument of student's entrepreneurial intentions.

We took instruments designed by Chen, Greene \& Crick (1998) and Van Gelderen, et al. (2008) as references in designing our measuring instrument of student's entrepreneurial intentions. The measuring questions are design from the dimensions of entrepreneurial interest, expectation, preparation, profession preference with limitation and are compiled by Likert's scale with six grades of answers. The results of principal component factor analysis indicate that the university student's entrepreneurial intentions factor can be measured by 5 questions, which provides $65.46 \%$ explanation of university student's entrepreneurial intentions variance while the results of reliability analysis indicate that reliability coefficient of the scale is 0.868 .

The measuring instruments of influencing factors of university student's entrepreneurial intentions

Analyzing the relevant literature, this paper discusses the impact of individual/psychological factors, family background factors and social environment factors on university student's entrepreneurial intentions (EI).

Individual / psychological factors:

personality traits refers to the measuring scale by Athayde (2009), we design 12 items to measure the university student's personality traits whose results of principal component factor analysis show that university student's personality traits can be measured from the dimensions of innovation orientation (IO), achievement orientation (AO), risk propensity (RP) and individual control (IC), which can explain $71.50 \%$ of university student's personality traits variance and the reliability coefficient of every factor ranges from 0.75 to 0.83 .

Entrepreneurial Attitudes (EA), Subjective Norm (SN), En- trepreneurial Self-Efficacy (ESE), entrepreneurial Competence (EC), refers to the measuring scale by Davidsson (1995), Liñán \& Chen (2009), Kautonen,et al,(2009), Man(2000), we design items to measure these aspects. The results of principal component factor analysis show that their factor consisting of items can provide explanation of variance from $62.56 \%$ to $68.89 \%$, and the reliability coefficient of every aspects ranges from 0.82 to 0.88 .

Individual/psychological factors also include Prior Entrepreneurial Experiences (PEE) and so on.

Family background factors contain grandparents' entrepreneurial experiences (GEE), parents' and siblings' entrepreneurial experiences (PSEE), relatives' entrepreneurial experiences (REE), and friends' entrepreneurial experiences (FEE).

Social background factors include:

Entrepreneurial Policy Supporting (ESP): The measurement of supporting policies is judged by the student's answer to the item "presently our country support entrepreneurial activities greatly".

Entrepreneurial Environment (EE): The results of principal component factor analysis show that the entrepreneurial environment factor consisting of two items can explain $81.81 \%$ variance and reliability coefficient is 0.79 .

Entrepreneurial Resistance (ER): It is measured from the aspects of self-confidence, fund, time, family support, commercial skills and entrepreneurial education. The results of principal component factor analysis show it can explain $49.32 \%$ of variance and the reliability coefficient is 0.79 .

\section{The Analytic Model of Student'S Entrepreneurial Intentions}

By literature review, this paper constructs a conceptual model which reflects the influence of individual/psychological factors, family background factors and social environment factors on university student's entrepreneurial intentions(as shown in Figure 1). The software such as SPSS and AMOS are used to analyze survey data.

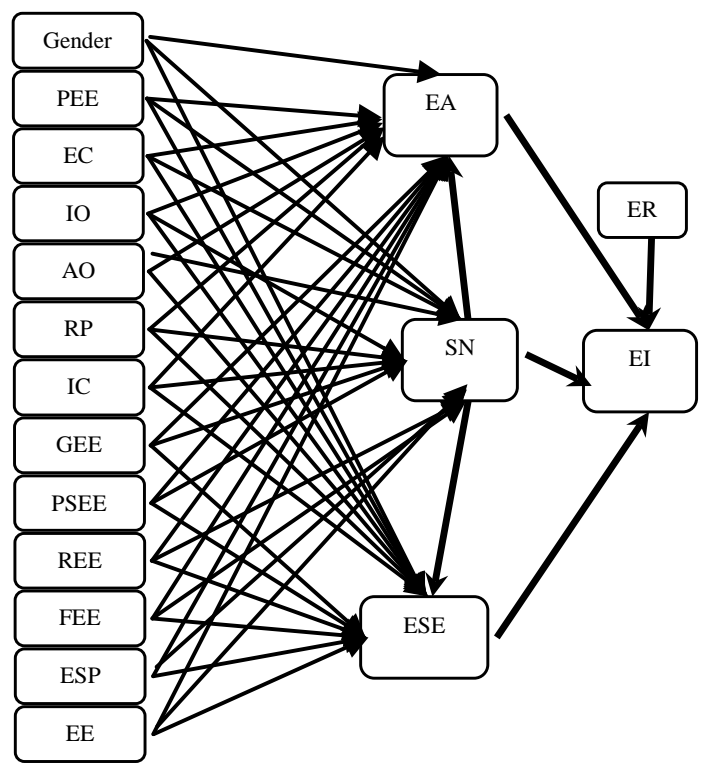

Figure 1.

Analytic Model for University Student's Entrepreneurial Intentions and the Influencing Factors. 


\section{Results}

\section{The Current Situation of University Student'S Entrepreneurial Intentions}

This paper uses five items including entrepreneurial interests, entrepreneurial expectations, entrepreneurial preparation and profession preference with limitation to measure university student's entrepreneurial intentions. Students' answers can be divided into six grades $(1=$ extremely agree, $6=$ extremely disagree). We can see that, to the item "My goal is to become an entrepreneur", $48.8 \%$ students choose extremely agree and agree while those choose disagree and extremely disagree account for $5.8 \%$. So we can say the percentage of students who take entrepreneurship as their goal is relatively high. To the item "I will try all my best tocreate my own business", 39.8\% students choose extremely agree and agree while those choose disagree and extremely disagree account for $11.5 \%$. This number shows university students have high expectation to entrepreneurship. To the item "I've already prepared everything for starting a business", 33.9\% students show extremely agree and agree while $13.9 \%$ of them show disagree and extremely disagree, which indicates that university students are actively preparing for starting their own business. Referring to the profession preference with limitation, the answers to item "Though failure, I will continue to create my own business until succeed" show that $40.0 \%$ students choose extremely agree and agree while only $8.1 \%$ of them show disagree and extremely disagree. To the item "Even though the strong rejection from parents, I will still commit to starting my business", 36.6\% students show extremely agree and agree while only $11.4 \%$ of them show disagree and extremely disagree, which indicates that even when they meet restrictions, university students have strong entrepreneurial intentions. Generally speaking, the results reflect strong entrepreneurial intentions of university students.

\section{Analysis of University Student'S Entrepreneurial Intentions and Their Influencing Factors Using Structural Equation Model}

In order to analyze more accurately the impact of individual/psychological factors, family background factors and social environment factors on university student's entrepreneurial intentions, we utilize structural equation modeling (SEM) to verify the conceptual model we constructed. In terms of the research and recommendation of Hau, Wen, \& Chen (2004), we select goodness of fit indicators like $\chi 2$, GFI, CFI, RMSEA, NNFI to examine the degree of model fit. During these indicators, it's better for Chi-square test not to reach significance. But the value of Chi-square is easily influenced by sample size. If the sample size is large, the value is easy to reach significance. CFI is a goodness of fit index with many strong points, which has less impact from sample size. Even though RMSEA is also influenced by sample size, it is insensitive to the misspecification model with few parameters, so it is also rarely influenced by sample size, the smaller the value of RMSEA is, the fitter the model is. The large value of NNFI (TLI) indicates a good fit, but this indicator would vary with the change of sample size.

Figure 2 shows the results of the analysis on conceptual model shown in Figure 1 by AMOS18.0 (standardized regression weights). In Figure 2, the path with significance is reserved $(\mathrm{p}<0.05)$. The goodness of fit index of this model is $\chi^{2}$ $=1189.138(d f=118, \mathrm{p}=0.001)$. Since this survey has large

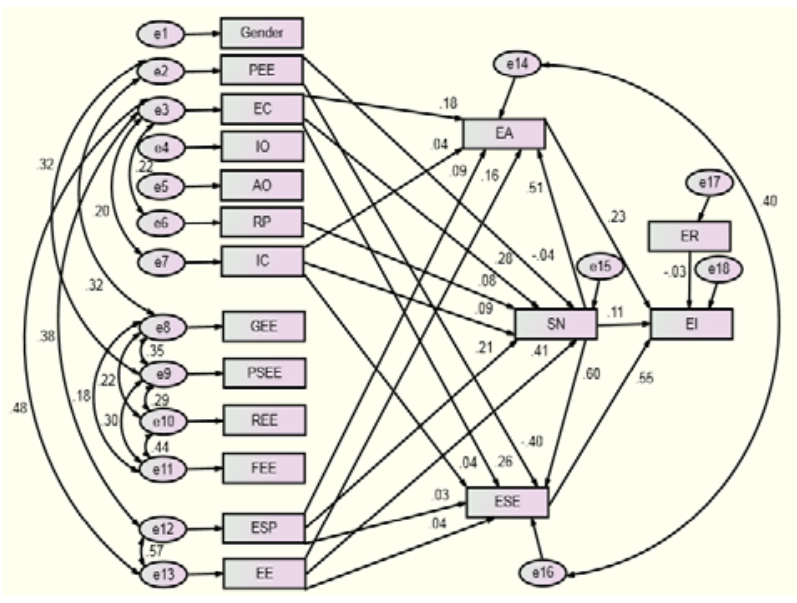

Figure 2.

Analysis on University Student's Entrepreneurial Intentions and Their Influencing Factors: Structural Equation Model $(n=2,010)$.

sample size $(n=2.010)$, it is easy to reach significance. GFI = 0.935 , RMSEA $=0.067$, CFI $=0.924$, NNFI $=0.902$. The values of the goodness of fit indexes suggest a reasonably highfitting model.

When we systematically examine the influence of individual/psychological factors, family background factors and social environment factors on university student's entrepreneurial intentions, we can see that: 1) In individual /psychological factors, university student's prior entrepreneurial experience has significantly positive impact on their subjective norm and entrepreneurial self-efficacy while entrepreneurial competence and individual's control exert significantly positive impact on their subjective norm, entrepreneurial self-efficacy and entrepreneurial attitude. Risk propensity exerts significant positive impact on student's subjective norm. The factors like gender, innovation orientation and achievement orientation have no significant impact on student's entrepreneurial attitude, subjective norm and entrepreneurial self-efficacy. 2) Family background factors like the entrepreneurship of grandparents, parents, relatives and friends have no significant impact on student's entrepreneurial attitude, subjective norm and entrepreneurial self-efficacy. They just have indirect connect with student's prior entrepreneurial experience. 3) In social environment factors, supporting policies, entrepreneurial environment exert significantly positive impact on entrepreneurial attitude, subjective norm and entrepreneurial self-efficacy of university students. 4) Subjective norm of university students also have significantly positive influence on their entrepreneurial attitude and entrepreneurial self-efficacy. 5) Entrepreneurial attitude, subjective norm and entrepreneurial self-efficacy of university students produce significantly positive impact on their entrepreneurial intentions while entrepreneurial resistance exerts significantly negative impact on their entrepreneurial intentions.

\section{Conclusions and Discussions}

Based on a sample survey conducted on 2,010 senior university students in Xi'an, China in 2009, this paper analyzes the entrepreneurial intentions of university students and their influencing factors. The results suggest that university students have strong entrepreneurial intentions. 
This paper systematically explores the influence of other factors such as individual/psychological factors, family background factors and social environment factors on the entrepreneurial intentions of university students. The results indicate that the subjective norm of university students has significantly positive influence on their entrepreneurial attitude and the entrepreneurial self-efficacy and all these factors exert significantly positive influence on their entrepreneurial Intentions. In individual/psychological factors, university student's entrepreneurial experience has significantly positive impact on their subjective norm and entrepreneurial self-efficacy. Entrepreneurial competence and individual's control of university student exert significantly positive impact on some intervening variables, such as student's entrepreneurial attitude, subjective norm and entrepreneurial self-efficacy, by which they produce significantly positive impact on student's entrepreneurial intentions. Student's risk propensity also exerts significant positive impact on their subjective norm. By this intervening variable, their entrepreneurial intentions are affected. Family background factors have no significant impact on student's entrepreneurial attitude, subjective norm, entrepreneurial self-efficacy and entrepreneurial intention. In social environment factors, both supporting policies and entrepreneurial environment of society exert significant positive impact on student's entrepreneurial attitude, subjective norm, and entrepreneurial self-efficacy, which exert significant positive impact on student's entrepreneurial intentions as intervening variables. Some entrepreneurial resistances caused by lack of self-confidence, funds, time, family support, business skills and entrepreneurial education have significantly negative impact on student's entrepreneurial intentions.

The results mentioned above are of significance to policy making. In three types of factors including individual/psychological factors, family background factors and social environment factors, except family background factors, individual/ psychological factors and social environment factors have significant influence on university student's entrepreneurial intentions. Family background factors of university students can't be controlled by policy, but individual/psychological factors and social environment factors can be regulated by education and relevant policy instruments. For instance, we can support university students for creating their own business and promote their entrepreneurial competence, self controllability and entrepreneurial self-efficacy to make them acquire more successful entrepreneurial experiences by taking a series of measures such as entrepreneurial education and entrepreneurial skill training, developing appropriate risk propensity, making a encouraging and supporting atmosphere, setting up entrepreneurial funds and incubating entrepreneurship of university students. By these education and supporting policies, individual/psychological status of university students and social environment are expected to be changed to promote university student's entrepreneurial intentions, reaching the goal of promoting employment by entrepreneurship.

\section{Acknowledgements}

This paper is supported by Program for New Century Excellent Talents in University of Ministry of Education (NCET08-0452), Program for Humanities and Social Sciences Planning Fund of MOE(2012) and Program for Humanities and Social Sciences Youth Fund in Western and Frontier Areas of
MOE(2012), and program of the Specialized Fund for the Basic Research Operating expenses Program of Central College in 2011(sk2011004), which is warmly thanked.

\section{REFERENCES}

Ajzen, I. \& Fishbein, M.(1977). Attitude-behavior Relations: A Theoretical Analysis and Review of Empirical Research. Psychological Bulletin, 84(5), 888-918.

Ajzen, I. (1987). Attitudes, Traits and Actions: Dispositional Prediction of Behavior in Personality and Social Psychology. Advances in Experimental Social Psychology, 20, 1-63.

Ajzen, I. (1991). The Theory of Planned Behavior. Organizational Behavior and Human Decision Processes, 50(2), 179 - 211.

Athayde, R. (2009). Measuring Enterprise Potential in Young People. Entrepreneurship Theory and Practice, 33(2), 481-500.

Bird, B. (1995). Toward a Theory of Entrepreneurial Competency. .In J.A.Katz \& R.H.Brockhaus, Sr.(Eds), Advances in Entrepreneurship, Firm Emergence, and Growth. 2,51-72. Greenwich, CN: JAI Press

Boyd, N.G. \& Vozikis, G.S. (1994).The Influence of Self-efficacy on the Development of Entrepreneurial Intentions and Actions. Entrepreneurship Theory and Practice, 18(4), 63-77.

Churchill,N.C. Carsrud, A.L., Gaglio, C.M., \& Olm, K.W. (1987). Entrepreneurs-mentors, Networks and Successful New Venture Development:An Exploratory Study. American Journal of Small Business, 12(2), 13-18.

Chandler, G.N. \& Jansen, E.(1992).The Founder's Self-assessed Competence and Venture Performance. Journal of business venturing,7(3),223-236

Chen, C.C., Greene, P.G., \& Crick, A. (1998). Does Entrepreneurial Self-efficacy Distinguish Entrepreneurs from Managers? Journal of Business Venturing, 13(4), 295-316.

Davidsson, P. (1995). Determinants of Entrepreneurial Intentions. Paper prepared for the RENT IX Workshop, Piacenza, Italy, 11. 23-24.

Elfving, J., Brännback, M., \& Carsrud, A. (2009) .Toward a Contextual Model of Entrepreneurial Intentions. In A.L.Carsrud, \& M.Brännback (Eds).Understanding the Entrepreneurial Mind, Opening the Black Box. New York: Springer, 23-33.

Fielden, S.L., Davidson, M.J., Dawe, A.J., \& Makin, P.J. (2003), Factors Inhibiting the Economic Growth of Female Owned Small Businesses in North West England. Journal of Small Business and Enterprise Development, 10( 2), 152-166.

Francis, D.H. \& Banning, K. (2001). Who Wants to be an Entrepreneur? Journal of Academy of Business Education, 1(2), 5-11.

Gartner, W. B. (1985). A Conceptual Framework for Describing the Phenomenon of New Venture Creation. The Academy of Management Review, 10(4), 696-706.

Garzón, M.D. (2010). A Comparison of Personal Entrepreneurial Competences between Entrepreneurs and CEOs in Service Sector. Service Business, 4,289-303.

Hau, J., Wen, Z., \& Cheng, Z.(2004). Structural Equation Model and Its Applications. Beijing: Educational Science Publishing House.

Kautonen, T., Tornikoski, E.T., \& Kibler, E. (2009). Entrepreneurial Intentions in the Third Age, the Impact of Perceived Age Norms. Small Business Economics, 37(2), 219-234.

Korunka, C., Frank, H., Lueger, M., \& Mugler, J. (2003). The Entrepreneurial Personality in the Context of Resources, Environment, and the Startup Process-A Configurational Approach. Entrepreneurship Theory and Practice, 28(1), 23-42.

Krueger, N. (1993). The Impact of Prior Entrepreneurial Exposure on Perceptions of New Venture Feasibility and Desirability. Entrepreneurship Theory and Practice, 18(1), 5-21.

Krueger, N. F,Jr \& Brazeal, D. V. (1994). Entrepreneurship Potential and Potential Entrepreneurs. Entrepreneurship Theory and Practice, 18(3),91-104.

Krueger, N. F,Jr \& Carsrud, A. L. (1993). Entrepreneurial Intentions: Applying the Theory of Planned Behavior. Entrepreneurship and Regional Development, 5(4), 315-330.

Krueger, N.F,Jr \& Dickson, P. (1993). Perceived Self-efficacy and 
Perceptions of Opportunity and Threat. Psychological Reports, 72(3), 1235-1240.

Krueger, N.F,Jr\& Dickson, P. (1994). How Believing in Ourselves Increases Risk Taking: Self-efficacy and Perceptions of Opportunity and Threat. Decision Sciences, 25,385-400.

Lee, L., Wong, P. K., Foo, M.D., \& Leung, A. (2011). Entrepreneurial Intentions: the Influence of Organizational and Individual Factors. Journal of Business Venturing, 26(1), 124-136.

Liñán, F. \& Chen, Y.W. (2009). Development and Cross-Cultural Application of a Specific Instrument to Measure Entrepreneurial Intentions. Entrepreneurship Theory and Practice, 33(3), 593-617.

Lüthje C. \& Frank, N. (2003). The Making of an Entrepreneur, Testing a Model of Entrepreneurial Intent Among Engineering Students at MIT. R\&D Management,33 (2),135-147.

Man, T. W. Y. (2000). Entrepreneurial Competencies of SME Owner/Managers in the Hong Kong Services Sector, a Qualitative Analysis. Journal of Enterprising Culture,8(3),235-254.

Matthews, C. \& Moser, S. (1995). Family Background and Gender: Implications for Interest in Small Firm Ownership. Entrepreneurship and Regional Development, 7, 365-377.

McClelland, D.C (1961). The achieving society. New York: Van No Strand.

Morris, M. H. \& Jones, F. F. (1999). Entrepreneurship in Established
Organizations: The Case of the Public Sector. Entrepreneurship Theory and Practice, 24(1), 71-91.

Schmitt-Rodermund, E. (2004).Pathways to Successful Entrepreneurship: Parenting, Personality, Early Entrepreneurial Competence, and Interests. Journal of Vocational Behavior, 65(3), 498-518.

Shapero, A. \& Sokol, L. (1982). The Social Dimensions of Entrepreneurship. In C.A. Kent, D.L. Sexton, \& K.H. Vesper (Eds.). Encyclopedia of Entrepreneurship. Englewood Cliffs, NJ: Prentice-Hall, 72-90.

Shaver, K.G. (1995). The Entrepreneurial Personality Myth. Business and Economic Review, 41(3), 20-23.

Shaver, K. G. \& Scott, L. R. (1991). Person, Process, Choice: the Psychology of New Venture Creation. Entrepreneurship Theory and Practice, 16(2), 23-45.

Stephen, F., Urbano, D., \& Hemmen, S. (2005). The Impact of Institutions on Entrepreneurial Activity. Managerial and Decision Economics, 26, 413-419.

Tabachnick, B. G. \& Fidell, L. S. (2001). Using Multivariate Statistics. Boston: Allyn and Bacon.

Van Gelderen, M., Brand, M., Van Praag, M., Bodewes, W., Poutsma, E., \& Van Gils, A.(2008). Explaining Entrepreneurial Intentions by Means of the Theory of Planned Behavior. Career Development International, 13(6), 538-559. 